\title{
Role of disease-modifying oral drugs in multiple sclerosis: A systematic review with meta-analysis
}

\author{
Minerva López-Ruiz ${ }^{1 *}$, Silvia Guzmán-Vázquez², Osvaldo Díaz-Álvarez², Yareli O. Buendía-López², and \\ Herman Soto-Molina² \\ ${ }^{1}$ Department of Neurology, Neurology and Neurosurgery Unit, Hospital General de México; ${ }^{2}$ HS Estudios Farmacoeconómicos, Mexico City, Mexico
}

\begin{abstract}
The purpose of the study was to evaluate the efficacy and safety of cladribine tablets compared with all oral therapies used in patients with relapsing-remitting multiple sclerosis (RRMS). A systematic review of the literature was conducted to identify published clinical trials about RRMS and a network meta-analysis was performed to determine the efficacy and safety of available treatments. We identified seven relevant studies, which were selected based on three criteria that allowed us to construct comparisons of efficacy and safety. Regarding the annualized relapse rate (ARR), there were no significant differences with respect to the decrease of this between cladribine tablets, dimethyl fumarate and fingolimod; although teriflunomide and cladribine tablets showed a significant difference. In relation to the mean number of gadolinium-enhanced T1 lesions, dimethyl fumarate showed a lower number of lesions $(-0.85[-1.21 ;-0.48])$, as did cladribine tablets versus placebo. No statistically significant differences were identified between cladribine tablets and fingolimod $(-0.08[-0.35 ; 0.19])$ and cladribine versus teriflunomide $(-0.28[-0.64 ; 0.08])$. While comparing adverse events that caused discontinuation, cladribine tablets showed an adequate safety profile, which was quantitatively similar to the compared drugs. Cladribine tablets demonstrated efficacy in terms of decrease of ARR and gadolinium-enhanced T1 lesions; although there is no significant difference between cladribine tablets, fingolimod and teriflunomide, the ARR is a stronger measure of efficacy compared to the number of T1 lesions made in contrast with long-term RRMS. Cladribine also demonstrated an adequate safety and tolerability profile promoting therapeutic adherence.
\end{abstract}

Key words: Relapsing-remitting multiple sclerosis. Cladribine tablets. Disease-modifying treatments.

\section{Papel de los fármacos orales modificadores de la enfermedad en la esclerosis múltiple: una revisión sistemática con metanálisis}

\section{Resumen}

El propósito del estudio fue evaluar la eficacia y seguridad de las tabletas de cladribina en comparación con todas las terapias orales utilizadas en pacientes con EMRR. Se realizó una revisión sistemática de la literatura para identificar ensayos clínicos publicados sobre EMRR y un metanálisis de red para determinar la eficacia y seguridad de los tratamientos disponibles. Identificamos 7 estudios relevantes, que se seleccionaron en base a 3 criterios que nos permitieron construir 
comparaciones de eficacia y seguridad. En cuanto a la tasa de recaída anualizada, no hubo diferencias significativas con respecto a la disminución de ésta entre las tabletas de cladribina, dimetilfumarato y fingolimod; aunque las tabletas de teriflunomida y cladribina mostraron una diferencia significativa. En relación con el número medio de lesiones $T 1$ potenciadas con gadolinio, dimetilfumarato mostró un menor número de lesiones (-0.85 [-1.21; -0.48]), al igual que las tabletas de cladribina frente a placebo. No se identificaron diferencias estadísticamente significativas entre las tabletas de cladribina $y$ fingolimod $(-0.08[-0.35 ; 0.19])$ y cladribina vs teriflunomida $(-0.28$ [-0.64; 0.08]). Al comparar los eventos adversos que causaron la suspensión, las tabletas de cladribina mostraron un perfil de seguridad adecuado, que fue cuantitativamente similar a los medicamentos comparados. Las tabletas de cladribina demostraron eficacia en términos de disminución de la tasa de recaída anualizada y lesiones $T 1$ potenciadas con gadolinio; Aunque no existe una diferencia significativa entre las tabletas de cladribina, fingolimod y teriflunomida, la tasa de recaída anualizada es una medida más fuerte de eficacia en comparación con el número de lesiones $T 1$ realizadas en contraste con la EMRR a largo plazo. Cladribina también demostró un perfil adecuado de seguridad y tolerabilidad que promueve la adherencia terapéutica.

Palabras claves: Esclerosis múltiple recurrente-remitente. Tabletas de cladribina. Tratamientos modificadores de la enfermedad.

\section{Introduction}

Multiple sclerosis (MS) is a chronic degenerative autoimmune disease of the central nervous system characterized by inflammatory demyelination resulting in axonal and neuronal damage. Relapsing-remitting MS (RRMS) being the most common type (85-90\%) $)^{1,2}$. Patients with RRMS suffer episodes that can cause fainting, this clinical condition can be disabling ${ }^{3}$. In Mexico, the prevalence reports ranges from 12 to 30 cases per 100,000 people $^{4}$.

Various therapies for MS require regular long-term self-injection that can result in patient dissatisfaction, which can severely affect therapeutic adherence and cause a secondary efficacy reduction ${ }^{5}$. Considering that the worldwide rate of non-adherence for MS is at $44 \%$, which is similar to that of chronic diseases ${ }^{6}$, oral medications have been introduced to improve adherence and, therefore, have an impact on therapeutic efficiency ${ }^{7}$. Oral cladribine (2-chloro-2'-deoxyadenosine) is an analog of adenosine deaminase resistant to deoxyadenosine $e^{8,9}$. It is a prodrug that requires intracellular phosphorylation, with a chlorine substitution in the purine ring. This protects it from degradation and increases its intracellular time ${ }^{10}$.

In treatment with cladribine tablets, patients in the 3.5 and $5.25 \mathrm{mg}$ group had fewer magnetic resonance imaging (MRI) lesions ${ }^{11}$ than those patients in the placebo group, for gadolinium-enhanced T1 lesions (mean 0.11 and 0.12 , respectively, vs. 0.91 in placebo) and T2 lesions (mean 0.38 and 0.33 , respectively, vs. 1.43 in placebo) ${ }^{12}$. There is not enough information to directly compare the oral therapeutic strategies available for RRMS in Mexico. The aim of this study was to evaluate the efficacy and safety of cladribine tablets compared to oral therapies currently used in patients with RRMS by means of a systematic review and a network meta-analysis, considering the annualized relapse rate (ARR), T1 lesions, and adverse events that cause discontinuation of treatment.

\section{Methods}

\section{Search method}

In accordance with the Cochrane methodology, the authors searched for data from 1980 to March 1, 2019, under the criteria of the population, intervention, control, and outcomes question "Evaluate the efficacy and safety of cladribine tablets in patients diagnosed with RRMS compared with dimethyl fumarate, fingolimod, and teriflunomide," on PubMed, Cochrane, ScienceDirect, Web of Science, the Health Economic Evaluations Database, EMBASE databases, and regional databases such as LILACs, Scielo Citation Index, Medigraphic, REDALYC, Imbiomed, and Artemisa. The MeSH terms used were "MS," "RRMS," "cladribine," "dimethyl fumarate," "fingolimod hydrochloride," and "teriflunomide," both in English, Spanish, and Portuguese, limited to controlled clinical that included oral disease-modifying therapies.

\section{Inclusion and exclusion criteria}

Primary data sources were articles from randomized controlled clinical trials (RCTs). To avoid bias, study selection and data extraction were performed by two independent reviewers. RCTs assessing the effect of cladribine tablets and dimethyl fumarate, fingolimod, or teriflunomide in direct comparison with placebo for the 
treatment of MS or RRMS were included, and a third reviewer provided consensus when there was disagreement on the inclusion of an article.

\section{Data extraction information}

Information was recorded on study design, selection criteria, population, patient characteristics, ARR, T1 lesions, and adverse events.

\section{Quality assessment}

The process of rating the quality of the best available evidence in the clinical studies was assessed following the approach proposed by the Grading of Recommendations, Assessment, Development, and Evaluation (GRADE) Working Group and in accordance with the GRADE Handbook.

\section{Outcomes}

Efficacy evaluation was performed based on the decrease of ARR and the change in the mean number of gadolinium-enhanced T1 lesions in the MRI. The safety profile was assessed by the number of patients who discontinued treatment due to adverse events.

\section{Statistical analysis}

Indirect comparisons were calculated using a network meta-analysis, since this is the most appropriate way of summarizing data to provide a series of unbiased effects obtained from direct and indirect comparisons. A random effects model was used as this is more appropriate than fixed effect models when there is heterogeneity between patient populations and between trials. To ensure a closed network, a placebo was used as a common point. Three interventions were used as comparators: dimethyl fumarate, fingolimod, and teriflunomide versus cladribine tablets; each study had both an intervention and a placebo. Direct evidence of the defined outcomes of each study was incorporated. Statistical significance was determined as $p>0.05$. All calculations were performed with the software $R$ version 3.5.2.

\section{Main results}

\section{Search results}

A total of 1034 articles were identified in the systematic review of the included databases. After duplicated removal, 761 papers were considered. Twenty-six of the potentially relevant articles were assessed for eligibility, and finally, seven clinical trials that met the efficacy and safety criteria were included (Chart 1). The characteristics of included studies are summarized in table 1.

Table 2 shows population data by intervention and cladribine dosage groups included in the analysis: cladribine tablets $3.5 \mathrm{mg}$, dimethyl fumarate $240 \mathrm{mg}$ twice daily, teriflunomide $14 \mathrm{mg}$, and fingolimod $0.5 \mathrm{mg}$. The posology of interventions was validated through the Basic Table and Catalogue of Health Sector Inputs (CBCISS) of the General Health Council (CSG) for the Mexican population.

From the seven selected studies, data from the annual relapse rate, the average of gadolinium-enhanced T1 lesions, were extracted when available (gadolinium-enhanced T1 lesions data were not available for the TOWER study); for safety data, adverse events that led to the interruption of the study drug were evaluated; this was presented as a rate (Table 3 ).

\section{Patient characteristics}

Studies were conducted from 2010 to 2014 with similar demographic characteristics, all studies included patients diagnosed with RRMS; as for study design, treatment arms of all studied had the common point a placebo group. All studies included a high percentage $(65.9-81 \%)$ of female patients (Table 2).

\section{Outcomes report}

Comparisons of cladribine tablets with dimethyl fumarate, fingolimod, and teriflunomide were made with efficacy, on the decrease of ARR and the change in the mean number of gadolinium reinforced $\mathrm{T} 1$ lesions in the MRI, and safety criteria data extracted through the systematic review.

\section{ARR}

Cladribine tablets showed no statistically significant differences with regard to the decrease of ARR compared to dimethyl fumarate and fingolimod, however, a lower relapse rate is shown with cladribine tablets when compared to placebo and teriflunomide (Chart 2).

\section{Gadolinium-enhanced T1 lesions}

In relation to the mean number of gadolinium-enhanced T1 lesions, treatment with cladribine reported a 


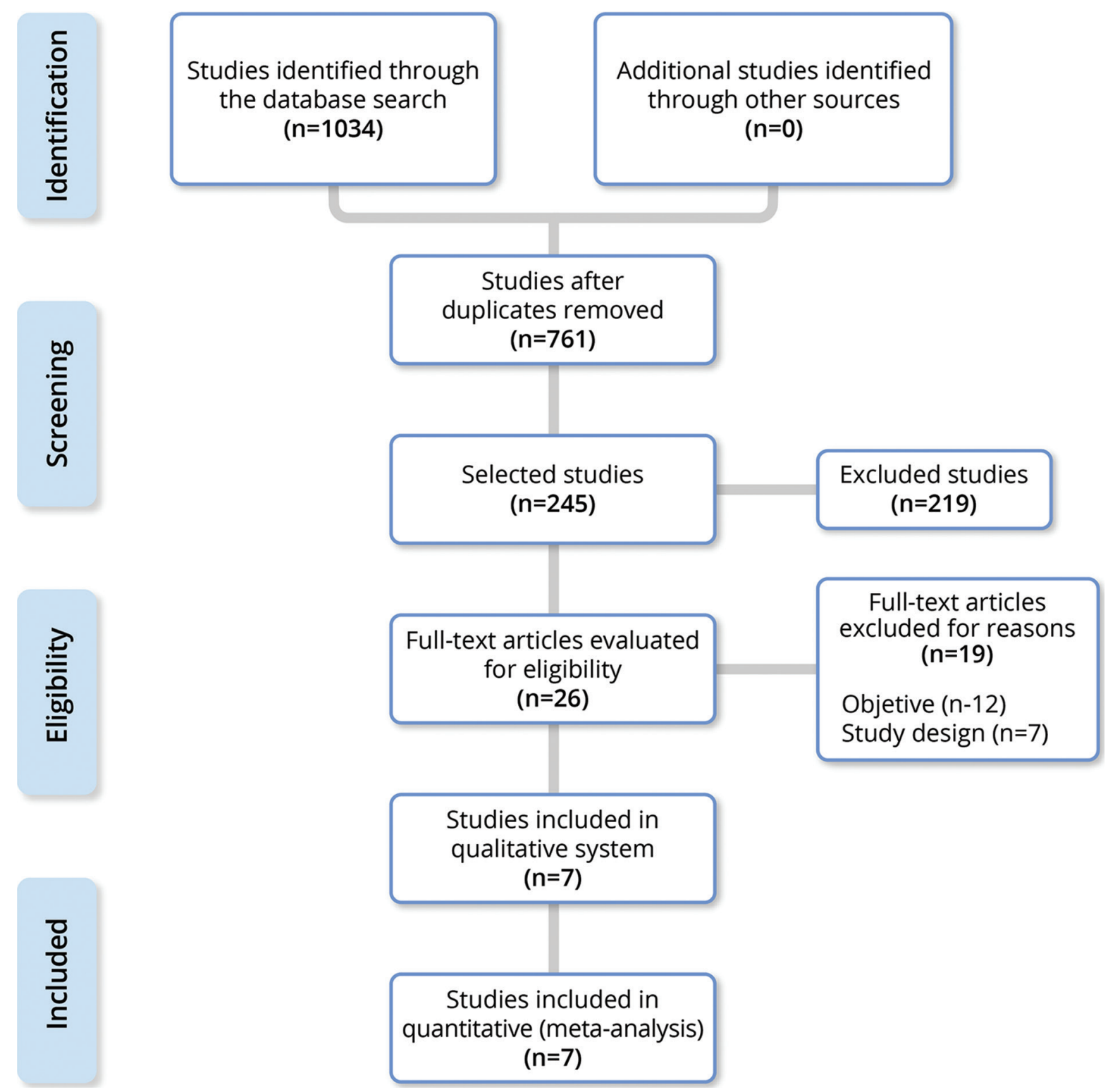

Chart 1. Flowchart summarizing the systematic review adapted to the PRISMA statement.

lower number of lesions when compared against dimethyl fumarate or placebo (Chart 3). This difference was statistically significant. On the other hand, no statistically significant differences were identified when comparing treatment with cladribine with fingolimod $(-0.08$ $[-0.35 ; 0.19])$ and teriflunomide $(-0.28[-0.64 ; 0.08])$.

\section{Adverse events that lead to a discontinuation of study drugs}

No significant differences were found between cladribine tablets and the other evaluated treatments
(Chart 4). In this case, the null effect is represented by the number one.

\section{Discussion}

In the absence of randomized clinical studies comparing all interventions for RRMS, a network meta-analysis is a plausible alternative for obtaining relative efficacy estimators. In Mexico, there are very few studies evaluating the efficacy and safety of treatments for MS.

A network meta-analysis by Siddiqui et al. (2018) in patients with RRMS showed that oral cladribine is among 
Table 1. Included articles characteristics

\begin{tabular}{|c|c|c|c|c|c|c|}
\hline Study & Study design & Participants & $\begin{array}{l}\text { Intervention and } \\
\text { dosing }\end{array}$ & n & $\begin{array}{l}\text { Duration } \\
\text { (Months) }\end{array}$ & Reported outcomes \\
\hline $\begin{array}{l}\text { CLARITY } 16 \\
\text { NCT00213135 }\end{array}$ & $\begin{array}{l}\text { Multicentric } \\
\text { RCT Phase III }\end{array}$ & $\begin{array}{l}\text { Adults. RRMS McDonald } \\
\text { criteria, EDSS }(0-5.5) \text {. At } \\
\text { least one relapse in the } \\
\text { past } 12 \text { months. }\end{array}$ & $\begin{array}{l}\text { Placebo } \\
\text { Cladribine } 3.5 \mathrm{mg} \\
\text { Cladribine } 5.25 \mathrm{mg}\end{array}$ & $\begin{array}{l}437 \\
433 \\
456\end{array}$ & 22 & $\begin{array}{l}\text { ARR, FRR. Time to first } \\
\text { relapse. } \\
\text { Mean number of } \\
\text { gadolinium-enhanced } \\
\text { T1 lesions, weighted } \\
\text { active lesions on T2 and } \\
\text { combined single lesions. } \\
\text { Incidence of treatment } \\
\text { emergent adverse } \\
\text { events. }\end{array}$ \\
\hline $\begin{array}{l}\text { FREEDOMS }{ }^{15} \\
\text { NCT00289978 }^{-1}\end{array}$ & $\begin{array}{l}\text { Double-blind } \\
\text { randomized, } \\
\text { placebo-CT, } \\
\text { Phase } 3\end{array}$ & $\begin{array}{l}\text { Adults. RRMS McDonald } \\
\text { criteria, EDSS }(0-5.5) \text {. }\end{array}$ & $\begin{array}{l}\text { Placebo } \\
\text { Fingolimod } 0.5 \mathrm{mg} \\
\text { Fingolimod } 1.25 \mathrm{mg}\end{array}$ & $\begin{array}{l}418 \\
425 \\
429\end{array}$ & 24 & $\begin{array}{l}\text { ARR. Time of disability } \\
\text { progression. } \\
\text { Number of gadolinium- } \\
\text { enhanced lesions. }\end{array}$ \\
\hline $\begin{array}{l}\text { FREEDOMS II }{ }^{17} \\
\text { NCT00355134 }\end{array}$ & $\begin{array}{l}\text { Double-blind } \\
\text { randomized, } \\
\text { placebo-CT, } \\
\text { parallel groups, } \\
\text { multicentric } \\
\text { Phase } 3 .\end{array}$ & $\begin{array}{l}\text { Adults. RRMS McDonald } \\
\text { criteria, EDSS (0-5.5). }\end{array}$ & $\begin{array}{l}\text { Placebo } \\
\text { Fingolimod } 0.5 \mathrm{mg} \\
\text { Fingolimod } 1.25 \mathrm{mg}\end{array}$ & $\begin{array}{l}355 \\
358 \\
370\end{array}$ & 22 & $\begin{array}{l}\text { ARR. Change } \\
\text { percentage in brain } \\
\text { volume. } \\
\text { Time of disability } \\
\text { progression. } \\
\text { Number and volume of } \\
\text { gadolinium-enhanced T1 } \\
\text { lesions. } \\
\text { Adverse events. }\end{array}$ \\
\hline $\begin{array}{l}\text { TEMSO }{ }^{18} \\
\text { NCT00134563 }\end{array}$ & $\begin{array}{l}\text { Double-blind } \\
\text { randomized, } \\
\text { placebo-CT, } \\
\text { parallel group, } \\
\text { Phase } 3\end{array}$ & $\begin{array}{l}\text { Adults. RRMS McDonald } \\
\text { criteria, EDSS }(0-5.5) \text {. At } \\
\text { least two relapses in the } \\
\text { previous } 2 \text { years or one } \\
\text { relapse in the previous } \\
\text { year, but not within } 60 \text { days } \\
\text { before randomization. }\end{array}$ & $\begin{array}{l}\text { Placebo } \\
\text { Teriflunomide } 7 \mathrm{mg} \\
\text { Teriflunomide } 14 \mathrm{mg}\end{array}$ & $\begin{array}{l}363 \\
365 \\
358\end{array}$ & 25 & $\begin{array}{l}\text { ARR. Disability } \\
\text { progression. } \\
\text { Total volume of the } \\
\text { lesion. } \\
\text { Number of unique active } \\
\text { lesions. } \\
\text { Adverse events. }\end{array}$ \\
\hline $\begin{array}{l}\text { TOWER }{ }^{19} \\
\text { NCT00751881 }\end{array}$ & $\begin{array}{l}\text { Double-blind } \\
\text { randomized, } \\
\text { placebo-CT, } \\
\text { Phase } 3\end{array}$ & $\begin{array}{l}\text { Adults. RRMS McDonald } \\
\text { criteria, EDSS }(0-5.5) \text {. At } \\
\text { least one relapse in the } \\
\text { last year or two relapses } \\
\text { in the last } 2 \text { years and } \\
\text { none in the } 30 \text { days prior } \\
\text { to randomization. }\end{array}$ & $\begin{array}{l}\text { Placebo } \\
\text { Teriflunomide } 7 \mathrm{mg} \\
\text { Teriflunomide } 14 \mathrm{mg}\end{array}$ & $\begin{array}{l}389 \\
407 \\
372\end{array}$ & 11 & $\begin{array}{l}\text { ARR. Time up to } 12 \\
\text { weeks of sustained } \\
\text { accumulation of } \\
\text { disability. } \\
\text { Adverse events. }\end{array}$ \\
\hline $\begin{array}{l}\text { DEFINE }^{20} \\
\text { NCT00420212 }^{2}\end{array}$ & $\begin{array}{l}\text { Double-blind } \\
\text { randomized, } \\
\text { placebo-CT, } \\
\text { Phase } 3\end{array}$ & $\begin{array}{l}\text { Adults. RRMS McDonald } \\
\text { criteria, EDSS }(0-5.5) \text {. At } \\
\text { least one relapse the year } \\
\text { before randomization. }\end{array}$ & $\begin{array}{l}\text { Placebo } \\
\text { Twice daily BG-12 } \\
240 \mathrm{mg} \\
\text { Three times a day } \\
\text { BG-12 } 240 \mathrm{mg}\end{array}$ & $\begin{array}{l}408 \\
410 \\
416\end{array}$ & 24 & $\begin{array}{l}\text { Relapses. } \\
\text { Number of gadolinium- } \\
\text { enhanced lesions. } \\
\text { Time of disability } \\
\text { progression. } \\
\text { Adverse events. }\end{array}$ \\
\hline $\begin{array}{l}\text { CONFIRM }^{21} \\
\text { NCT00451451 }^{2}\end{array}$ & $\begin{array}{l}\text { Double-blind } \\
\text { randomized, } \\
\text { placebo-CT, } \\
\text { Phase } 3\end{array}$ & $\begin{array}{l}\text { Adults. RRMS McDonald } \\
\text { criteria, EDSS }(0-5) \text {. At } \\
\text { least one relapse in the } \\
\text { past } 12 \text { months or at least } \\
\text { one gadolinium-enhanced } \\
\text { lesion } 0-6 \text { weeks before } \\
\text { randomization. }\end{array}$ & $\begin{array}{l}\text { Placebo } \\
\text { Twice daily BG-12 } \\
240 \mathrm{mg} \\
\text { Three times a day } \\
\text { BG-12 } 240 \mathrm{mg} \\
\text { Glatiramer acetate } \\
20 \mathrm{mg}\end{array}$ & $\begin{array}{l}363 \\
359 \\
\\
345 \\
350\end{array}$ & 22 & $\begin{array}{l}\text { ARR. Number of new T2 } \\
\text { hypertensive lesions or } \\
\text { increasing number of } \\
\text { T2 lesions, T1-enhanced } \\
\text { images. } \\
\text { Adverse events. }\end{array}$ \\
\hline
\end{tabular}

RCT: randomized controlled clinical trial; EDSS: expanded disability status scale; ARR: annualized relapse rate; FRR: free relapse rate.

the most effective disease-modifying treatments and has an adequate safety profile comparable to other treatments, it also presents a significant reduction in relapse rate compared to teriflunomide and even parenteral drugs $^{13}$. In addition to this, Papadopoulos et al. conducted a safety analysis on the likelihood to help or harm, defined as the ratio of number needed to harm to the number needed to treat with respect to adverse events causing discontinuation of treatment (NNTH AE-D), which showed favorable evidence for cladribine $(72[95 \% \mathrm{Cl} 27.9$ to 
Table 2. Population characteristics

\begin{tabular}{|c|c|c|c|c|c|}
\hline Reference & $\begin{array}{l}\text { Clinical form of } \\
\text { the disease }\end{array}$ & Study arms & $\begin{array}{l}\text { Sample } \\
\text { size }\end{array}$ & Age & $\%$ women \\
\hline \multirow[t]{3}{*}{ Giovannoni et al., $2010^{16}$} & \multirow[t]{3}{*}{ RRMS } & Placebo & 437 & $38.7 \pm 9.9$ & $288(65.9)$ \\
\hline & & Cladribine $3.5 \mathrm{mg}$ & 433 & $37.9 \pm 10.3$ & $298(68.8)$ \\
\hline & & Cladribine $5.25 \mathrm{mg}$ & 456 & $39.1 \pm 9.9$ & $312(68.4)$ \\
\hline \multirow[t]{3}{*}{ Kappos et al., $2010^{15}$} & \multirow[t]{3}{*}{ RRMS } & Placebo & 418 & $37.2 \pm 8.6$ & $298(71.3)$ \\
\hline & & Fingolimod $0.5 \mathrm{mg}$ & 425 & $36.6 \pm 8.8$ & $296(69.6)$ \\
\hline & & Fingolimod $1.25 \mathrm{mg}$ & 429 & $37.4 \pm 8.9$ & $295(68.8)$ \\
\hline \multirow[t]{3}{*}{ Calabresi et al., $2014^{17}$} & \multirow[t]{3}{*}{ RRMS } & Placebo. & 355 & $40.1 \pm 8.4$ & $288(81)$ \\
\hline & & Fingolimod $0.5 \mathrm{mg}$ & 358 & $40.6 \pm 8.4$ & $275(77)$ \\
\hline & & Fingolimod $1.25 \mathrm{mg}$ & 370 & $40.9 \pm 8.9$ & $281(76)$ \\
\hline \multirow[t]{3}{*}{$0^{\prime}$ Connor et al., $2011^{18}$} & \multirow[t]{3}{*}{ RRMS } & Placebo. & 363 & $38.4 \pm 9.0$ & $275(75.8)$ \\
\hline & & Teriflunomide $7 \mathrm{mg}$ & 365 & $37.4 \pm 9.0$ & $255(69.7)$ \\
\hline & & Teriflunomide $14 \mathrm{mg}$ & 358 & $37.8 \pm 8.2$ & $255(71.0)$ \\
\hline \multirow[t]{3}{*}{ Confavreux et al., $2014^{19}$} & \multirow[t]{3}{*}{ RRMS } & Placebo & 389 & $38.1 \pm 9.1$ & $273(70)$ \\
\hline & & Teriflunomide 7 mg & 407 & $37.4 \pm 9.4$ & $300(74)$ \\
\hline & & Teriflunomide $14 \mathrm{mg}$ & 372 & $38.2 \pm 9.4$ & $258(69)$ \\
\hline \multirow[t]{3}{*}{ Gold et al., $2012^{20}$} & \multirow[t]{3}{*}{ RRMS } & Placebo & 408 & $38.5 \pm 9.1$ & $306(75)$ \\
\hline & & Twice a day BG-12 $240 \mathrm{mg}$ & 410 & $38.1 \pm 9.1$ & $296(72)$ \\
\hline & & Three times a day BG-12 $240 \mathrm{mg}$ & 416 & $38.8 \pm 8.8$ & $306(74)$ \\
\hline \multirow[t]{4}{*}{ Fox et al., $2012^{21}$} & \multirow[t]{4}{*}{ RRMS } & Placebo & 363 & $36.9 \pm 9.2$ & $251(69)$ \\
\hline & & Twice a day BG-12 $240 \mathrm{mg}$ & 359 & $37.8 \pm 9.4$ & $245(68)$ \\
\hline & & Three times a day BG-12 $240 \mathrm{mg}$ & 345 & $37.8 \pm 9.4$ & $250(72)$ \\
\hline & & Glatiramer acetate $20 \mathrm{mg}$ & 350 & $36.7 \pm 9.1$ & $247(71)$ \\
\hline
\end{tabular}

RRMS: relapsing-remitting multiple sclerosis.

$-129.5])^{14}$. In this context, our findings are consistent with published reports of cladribine and its safety profile.

In relation to the ARR, cladribine tablets had no significant difference in its effect on relapses compared with the other interventions, however, it had a statistically significant when compared to teriflunomide. The CLARITY study reports an effect size with a greater than $50 \%$ decrease in annual relapses, a decrease in disability of up to $30 \%$, and the effect was consistent in sub-population analysis.

The analysis for the gadolinium-enhanced T1 lesions outcome found that the effect of cladribine was comparable to those presented with fingolimod ${ }^{15}$. Although there is no significant difference between cladribine, fingolimod, and teriflunomide, it must be taken into to consideration that the reported ARR is a stronger measure of efficacy compared to the number of $\mathrm{T} 1$ lesions.

The evidence provided by the therapeutic options individually, allows us to put the agents that are used on a daily basis into context, seen in a broader way. This review of oral administered drugs makes it possible to assess important clinical outcomes, while at the same time taking into account that the difference between the characteristics of each drug may affect the clinical outcome. At present, a range of disease-modifying drugs with different mechanisms of action is available, with simplified dosages and periodicity schedules. Cladribine tablets are a therapeutic option that offers the expected therapeutic effect, with an annualized administration scheme that confers comfort to the 
Rev Mex Neuroci. 2021;22(1)

Table 3. Data included in the meta-analysis

\begin{tabular}{|c|c|c|c|c|c|c|c|c|c|c|c|c|}
\hline \multirow[b]{3}{*}{ Study } & \multicolumn{4}{|c|}{ Annualized relapse rate } & \multicolumn{4}{|c|}{ Gadolinium-enhanced T1 Lesions } & \multicolumn{4}{|c|}{$\begin{array}{l}\text { Adverse events leading to } \\
\text { discontinuation of the study drug }\end{array}$} \\
\hline & \multicolumn{2}{|c|}{ Placebo } & \multicolumn{2}{|c|}{ Intervention } & \multicolumn{2}{|c|}{ Placebo } & \multicolumn{2}{|c|}{ Intervention } & \multicolumn{2}{|c|}{ Placebo } & \multicolumn{2}{|c|}{ Intervention } \\
\hline & n & Rate & n & Rate & $\bar{\mu}$ & SD & $\bar{\mu}$ & SD & $\mathbf{n}$ & Rate & $\mathbf{n}$ & Rate \\
\hline CLARITY $^{16}$ & 437 & $33 \%$ & 433 & $14 \%$ & 0.91 & 2.10 & 0.12 & 2.7 & 435 & $2.07 \%$ & 430 & $3.49 \%$ \\
\hline FREEDOMS ${ }^{15}$ & 418 & $40 \%$ & 425 & $18 \%$ & 1.1 & 2.40 & 0.2 & 0.80 & 418 & $7.66 \%$ & 425 & $7.53 \%$ \\
\hline FREEDOMS II ${ }^{17}$ & 355 & $40 \%$ & 358 & $21 \%$ & 1.2 & 2.97 & 0.4 & 1.84 & 355 & $10.42 \%$ & 358 & $18.44 \%$ \\
\hline TEMSO $^{18}$ & 363 & $54 \%$ & 358 & $37 \%$ & 1.33 & 2.96 & 0.26 & 1.16 & 360 & $8.06 \%$ & 358 & $10.89 \%$ \\
\hline TOWER ${ }^{19}$ & 388 & $50 \%$ & 370 & $32 \%$ & - & - & - & - & 385 & $6.23 \%$ & 371 & $15.63 \%$ \\
\hline DEFINE ${ }^{20}$ & 408 & $36 \%$ & 410 & $17 \%$ & 1.8 & 4.20 & 0.1 & 0.60 & 408 & $13.48 \%$ & 410 & $15.85 \%$ \\
\hline CONFIRM $^{21}$ & 363 & $40 \%$ & 359 & $22 \%$ & 2 & 5.60 & 0.5 & 1.70 & 363 & $10.47 \%$ & 359 & $12.26 \%$ \\
\hline
\end{tabular}

$\bar{\mu}$ average; SD: standard deviation.

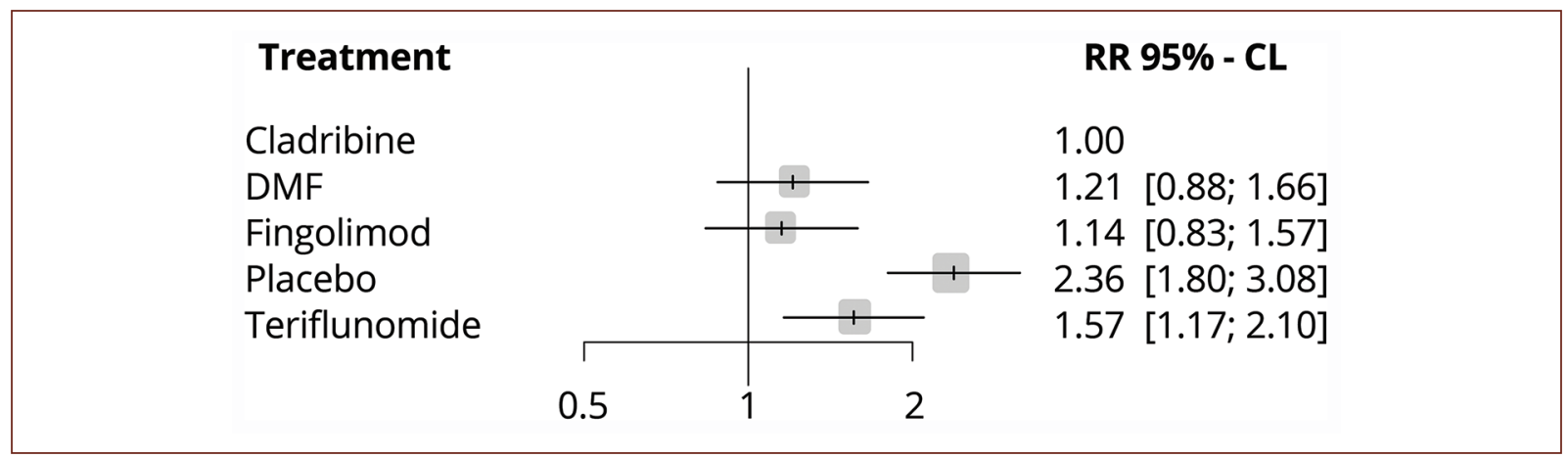

Chart 2. Forest plot in patients with relapsing-remitting multiple sclerosis randomized to receive cladribine tablets, dimethyl fumarate (DMF), fingolimod, teriflunomide, or placebo treatment with $95 \%$ confidence level and relative risk for annualized relapse rates (ARRs).

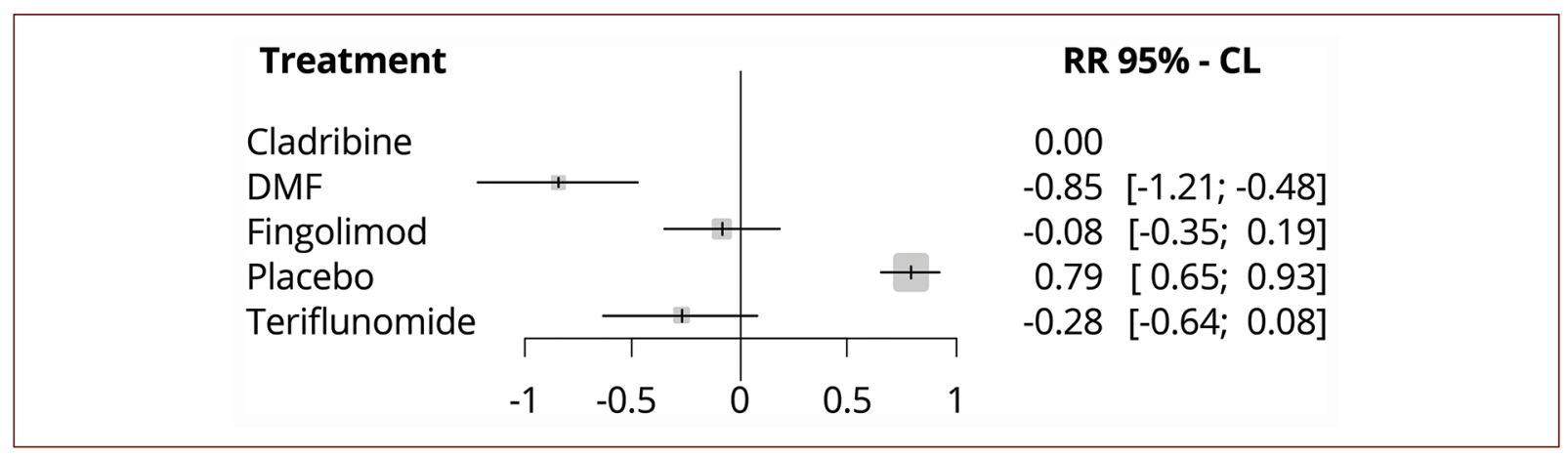

Chart 3. Forest plot in patients with relapsing-remitting multiple sclerosis randomized to receive cladribine tablets, dimethyl fumarate (DMF), fingolimod, teriflunomide, or placebo treatment with $95 \%$ confidence level. Difference in gadolinium-enhanced T1 lesions means per patient. 


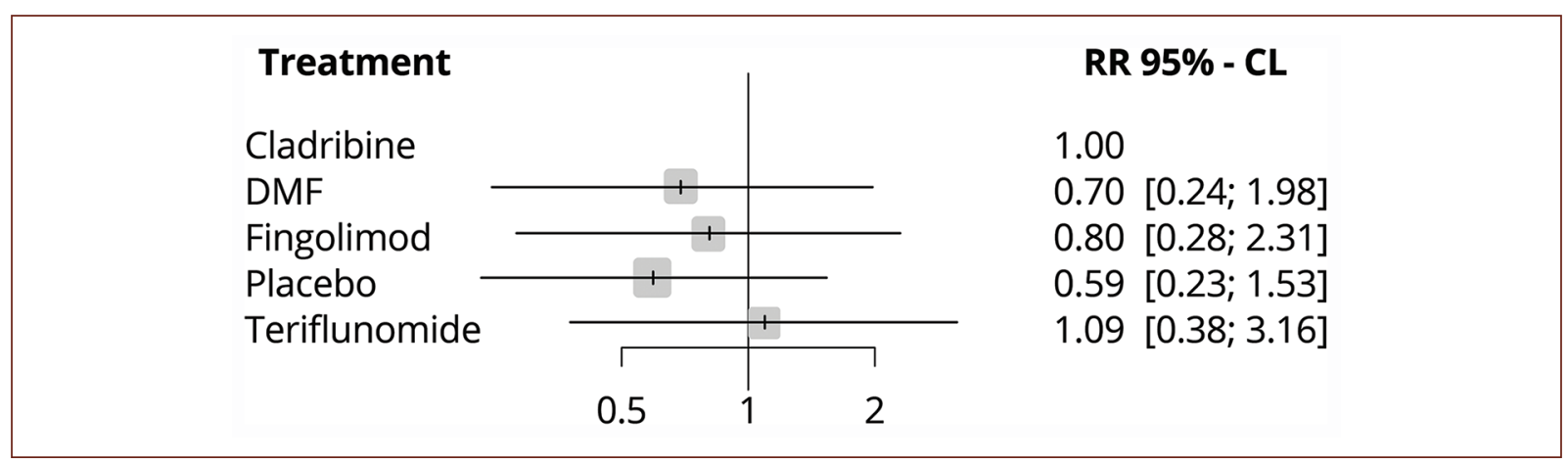

Chart 4. Forest plot in patients with randomized relapsing-remitting multiple sclerosis to receive cladribine tablets, dimethyl fumarate (DMF), fingolimod, teriflunomide, or placebo treatment with $95 \%$ confidence level. Relative risk for adverse events causing treatment interruption.

Table 4. Safety profile of oral drugs

\begin{tabular}{|c|c|c|c|c|}
\hline Drug & Short-term side effects & Long-term efficacy & Long-term side effects & Important safety aspects \\
\hline Fingolimod & $\begin{array}{l}\text { Bradycardia, average of } \\
8 \text { bpm during the first } \\
\text { infusion }(2.3 \%) \text {. } \\
\text { Macular edema. } \\
\text { Elevation of liver function } \\
\text { enzymes. } \\
\text { Mild infections. } \\
\text { Herpes zoster infection. }\end{array}$ & $\begin{array}{l}\text { Data to } 7 \text { years: } 84-96 \% \text { free of } \\
\text { gadolinium lesions, } 70 \% \text { free of } \\
\text { T2-weighted lesions. } \\
\text { Average PBVC: }-2.8 \text { for more } \\
\text { than } 84 \text { months. }\end{array}$ & $\begin{array}{l}\text { No new aspects to known } \\
\text { side effects of crucial } \\
\text { tests. }\end{array}$ & $\begin{array}{l}\text { Herpes zoster infection in a } \\
\text { small number of patients. } \\
\text { PML risk 1/18.000. }\end{array}$ \\
\hline $\begin{array}{l}\text { Dimethyl } \\
\text { fumarate }\end{array}$ & $\begin{array}{l}\text { Flushing or redness. } \\
\text { Gastrointestinal irritation. } \\
\text { Lymphopenia. }\end{array}$ & $\begin{array}{l}\text { ARR from years } 1-5: 0.202 \text {, } \\
0.163,0.139,0.143 \text {, and } 0.138 \text {. }\end{array}$ & $\begin{array}{l}\text { PML, so far } 5 \text { patients } \\
>230,000 \text { who have been } \\
\text { treated with DMF, some } \\
\text { cases reported with } \\
\text { FUMADERM. }\end{array}$ & $\begin{array}{l}\text { PML risk of } 1 / 50,000 \text {. } \\
\text { In people }>50 \text { years, early } \\
\text { lymphocyte reduction is } \\
\text { associated with an } \\
\text { increased risk of PML. }\end{array}$ \\
\hline Teriflunomide & $\begin{array}{l}\text { Asymptomatic increase of } \\
\text { alanine aminotransferase. } \\
\text { Headache. } \\
\text { Diarrhea. } \\
\text { Hair thinning. } \\
\text { Nausea. }\end{array}$ & $\begin{array}{l}9 \text { years of TEMSO follow-up. } \\
55 \% \text { relapse free. } \\
\text { Stable EDSS scale average } \\
>50 \% \text { without progression. }\end{array}$ & $\begin{array}{l}\text { No pattern of malignancies, } \\
\text { especially hematologic } \\
\text { cancers such as leukemia } \\
\text { or lymphoproliferative } \\
\text { tumors. }\end{array}$ & \\
\hline Cladribine & $\begin{array}{l}\text { Lymphopenia. } \\
\text { Herpes zoster infection } \\
(<10 \%) \text {. } \\
\text { There is no increased risk } \\
\text { of malignant tumors. }\end{array}$ & Data not available & Data not available & $\begin{array}{l}\text { No reported cases of PML } \\
\text { in multiple sclerosis. }\end{array}$ \\
\hline
\end{tabular}

*PML: progressive multifocal leukoencephalopathy (adapted from Faissner and Gold, 2018) ${ }^{22}$.

patient and his caregiver, which undoubtedly favors therapeutic adherence. Cladribine tablets reach quickly and steadily its effect on lymphocytes after an administration, resulting in a good efficacy, safety, and proven tolerability profile.

The specific evidence establishes that all interventions require careful patient selection. According to the safety profile and tolerability of cladribine tablets, in the
CLARITY study ${ }^{16}$ due to its dose-dependent mechanism action, the most common adverse effect was lymphopenia, increasing the risk of an opportunistic infection; however, there are no reports of progressive multifocal leukoencephalopathy (PML), bradycardia, or macular edema attributable to cladribine tablets on patients with MS (Table 4). In relation to the safety profile, this meta-analysis shows no statistically significant 
differences in adverse effects, but simply a different pattern.

\section{Limitations and strengths of the study}

The main limitation of the study remains that on Mexican population, regarding this disease, information is poor or scarce; so the results of the analysis must be interpreted with caution. Nevertheless, international literature did not provide randomized clinical trials that would allow direct comparisons, making an indirect comparison an alternative to explore the existent and limited alternatives.

The main strength of the study is the use of a network meta-analysis with a random effects model that allows homogenizing the main biases within the analysis to make indirect comparisons. The selection of the articles was carried out by specialists on the subject and in the event of any lack of concession, a third reviewer intervened.

\section{Conclusion}

Cladribine tablets demonstrated efficacy in terms of decrease of ARR and gadolinium-enhanced T1 lesions made in contrast with patients with long-term RRMS, as well as a good safety profile and tolerability that promote therapeutic adherence, becoming an appropriate therapeutic option for patients with RRMS. It is important to evaluate the different therapeutic interventions from a standardized perspective for an appropriate treatment selection that positively delays or modifies the natural course of this disease and can contribute to the quality of life of patients with RRMS.

\section{Acknowledgments}

We want to thank the entire team that contributed significantly to the development of this article, including Giselle Callejas Ortega, José Luis Pedro Méndez, and other reviewers involved.

\section{Funding}

The preparation of this review was supported by Merck external funding. This article was made with the full autonomy of the authors LRM, GVS, DAO, BLYO, and $\mathrm{SMH}$.

\section{Con『icts of interest}

The authors LRM, GVS, DAO, BLYO, and SMH are responsible for the article content and declare have received honoraria from Merck. GVS, DAO, BLYO, and $\mathrm{SMH}$ are employees of HS Estudios Farmacoeconómicos S.A. de C.V., are ISPOR members and declare have received honoraria also from Roche, Novartis, Sanofi, Pfizer, and Biogen as well as have served in a consulting or advisory role for Roche, Celgene, and AstraZeneca. The authors have no other relevant affiliations or financial involvement with any organization or entity with a financial interest in or financial conflict with the subject matter or materials discussed in the manuscript apart from those disclosed.

\section{Ethical disclosures}

Protection of human and animal subjects. The authors declare that no experiments were performed on humans or animals for this study.

Con $\nabla$ dentiality of data. The authors declare that they have followed the protocols of their work center on the publication of patient data.

Right to privacy and informed consent. The authors declare that no patient data appear in this article.

\section{References}

1. Noseworthy $\mathrm{JH}$, Lucchinetti $\mathrm{C}$, Rodriguez M, Weinshenker BG. Multiple sclerosis. N Engl J Med. 2000;343:938-952.

2. Lublin FD, Reingold SC, Cohen JA, Cutter GR, Sørensen PS Thompson AJ, et al. Defining the clinical course of multiple sclerosis: the 2013 revisions. Neurology. 2014:83:278-86.

3. Ziemssen T. Symptom management in patients with multiple sclerosis. J Neurol Sci. 2011;311:S48-52.

4. Rivera VM, Medina MT, Duron RM, Macias MA. Multiple sclerosis care in Latin America. Neurology. 2014;82:1660-1.

5. Giovannoni G, Southam E, Waubant E. Systematic review of disease-modifying therapies to assess unmet needs in multiple sclerosis: tolerability and adherence. Mult Sclerosis. 2012;18:932-46.

6. World Health Organization. Adherence to Long-term Therapies. Evidence for Action (WHO/MN/0.30.1). Washington, DC: World Health Organization; 2003. p. 211.

7. Bruce JM, Hancock LM, Lynch SG. Objective adherence monitoring in multiple sclerosis: initial validation and association with self-report. Mult Sclerosis 2010;16:112-20.

8. Beutler E. Cladribine (2-chlorodeoxyadenosine). Lancet. 1992;340:952-6.

9. Brousil JA, Roberts RJ, Schlein AL. Cladribine: an investigational immunomodulatory agent for multiple sclerosis. Ann Pharmacother. 2006;40:1814-21.

10. Science Medicines Health. Summary of Product Characteristics: mavenclad (cladribine). Netherlands: European Medicines Agency, Science Medicines Health; 2017. p. 1-41.

11. Alva CIE. El Significado Psicológico de la Experiencia del Parto Con el Apoyo Continuo de Doula: un Estudio Comparativo Con Redes Semánticas Naturales. Colima: Tesis de Maestría, Universidad de Colima; 2006

12. Giovannoni G. Cladribine to treat relapsing forms of multiple sclerosis. Neurotherapeutics. 2017; 14:874-87.

13. Siddiqui MK, Khurana IS, Budhia S, Hettle R, Harty G, Wong SL. Systematic literature review and network meta-analysis of cladribine tablets versus alternative disease-modifying treatments for relapsing-remitting multiple sclerosis. Curr Med Res Opin. 2018:34:1361-71. 
14. Papadopoulos D, Mitsikostas DD. Oral disease-modifying treatments for relapsing multiple sclerosis: a likelihood to achieve no evidence of disease activity or harm analysis. CNS Drugs. 2018:32:1069-78.

15. Kappos L, Radue EW, O'Connor P, Polman C, Hohlfeld R, Calabresi P, et al. A placebo-controlled trial of oral fingolimod in relapsing multiple sclerosis. N Engl J Med. 2010;362:387-401.

16. Giovannoni G, Comi G, Cook S, Rammohan K, Rieckmann P, Soelberg Sørensen $\mathrm{P}$, et al. A placebo-controlled trial of oral cladribine for relapsing multiple sclerosis. N Engl J Med. 2010;362:416-26.

17. Calabresi PA, Radue EW, Goodin D, Jeffery D, Rammohan KW, Reder AT, et al. Safety and efficacy of fingolimod in patients with relapsing-remitting multiple sclerosis (FREEDOMS II): a double-blind randomised, placebo-controlled, phase 3 trial. Lancet Neurol. 2014;13:545-56.
18. O'Connor P, Wolinsky JS, Confavreux C, Comi G, Kappos L, Olsson TP, et al. Randomized trial of oral teriflunomide for relapsing multiple sclerosis. N Engl J Med. 2011;365:1293-303.

19. Confavreux C, O'Connor P, Comi G, Freedman MS, Miller AE, Olsson TP, et al. Oral teriflunomide for patients with relapsing multiple sclerosis (TOWER): a randomised, double-blind, placebo-controlled, phase 3 trial. Lancet Neurol. 2014;13:247-56.

20. Gold R, Kappos L, Arnold DL, Bar-Or A, Giovannoni G, Selmaj K, et al. Placebo-controlled phase 3 study of oral BG-12 for relapsing multiple sclerosis. N Engl J Med 2012;367;1098-107.

21. Fox RJ, Miller DH, Phillips JT, Hutchinson M, Havrdova E, Kita M, et al Placebo-controlled phase 3 study of oral BG-12 or glatiramer in multiple sclerosis. N Engl J Med. 2012;367:1087-97.

22. Faissner S, Gold R. Efficacy and safety of the newer multiple sclerosis drugs approved since 2010. CNS Drugs. 2018;32:269-87. 